\title{
Vapor Condensation in Rice Fields and Its Contribution to Crop Evapotranspiration in the Subtropical Monsoon Climate of China
}

\author{
XiaOyin LiU, JunZeng Xu, AND Shihong Yang \\ College of Agricultural Engineering, and State Key Laboratory of Hydrology-Water Resources and \\ Hydraulic Engineering, Hohai University, Nanjing, Jiangsu, China \\ JIANGANG ZHANG AND YIJIANG WANG \\ Kunshan Water Conservancy Engineering Quality and Safety Supervision and Water Technology Popularization Station, \\ Kunshan, Jiangsu, China
}

(Manuscript received 28 October 2017, in final form 24 April 2018)

\begin{abstract}
While vapor condensation in arid and semiarid areas has garnered much attention, such information is scarce for humid crop production areas such as rice fields. In a water-saving irrigation (WSI) rice field, highprecision weighed microlysimeters allowed the direct and independent quantification of condensation over plants (Cc) and soil (Cs) through mass balance calculations. The occurrence frequency and rate of Cc generally exceeded that of Cs. Predominantly occurring between sunset and sunrise, particularly between 0400 and 0500 local time, Cc showed an overall maximum rate of $0.096 \mathrm{~mm} \mathrm{~h}^{-1}$. In contrast, Cs was highest between 0100 and 1100 local time and showed an overall maximum rate of $0.044 \mathrm{~mm} \mathrm{~h}^{-1}$. The occurrence of Cc, unlike that of $\mathrm{Cs}$, required a surface temperature lower than the ambient temperature or dewpoint. Of 65 rain-free days, $\mathrm{Cc}$ and Cs occurred on 60 and 33 days, respectively. Seasonal Cc, Cs, and Cc + Cs were estimated as 32.3, 3.1 , and $35.4 \mathrm{~mm}$, respectively, and their contributions to seasonal rice transpiration $T$, evaporation $E$, and evapotranspiration (ET) were $9.5 \%, 1.6 \%$, and $6.7 \%$, respectively. The seasonal Cc + Cs was similar in magnitude to a routine irrigation quota and accounted for $10.8 \%$ of rainfall and $14.4 \%$ of irrigation in the WSI rice field. Therefore, vapor condensation in rice fields in a subtropical monsoon climate is an important component of the hydrological cycle and cannot be ignored when tabulating the field water balance, calculating field water consumption, or in irrigation scheduling.
\end{abstract}

\section{Introduction}

Vapor condensation, including dewfall and hygroscopic water, is a process whereby water vapor from the atmosphere is cooled and condenses as a liquid on a given surface cooler than the dewpoint temperature of the surrounding air (Glenn et al. 1996; Graf et al. 2008). It is an essential meteorological process (Madeira et al. 2001; Kabela et al. 2009) and is an important component of the land surface moisture cycle (Yan and $\mathrm{Xu}$ 2010; Lü et al. 2011). The process of vapor condensation has drawn interdisciplinary interest from such fields as meteorology, hydrology, ecology, and agriculture (Llorente et al. 2000; Hornbuckle et al. 2006; Malek et al. 1999; Hanisch et al. 2015; Kabela et al. 2009).

Corresponding author: Junzeng Xu, xjz481@hhu.edu.cn
Besides providing a potentially critical environmental moisture source (Zhang et al. 2007; Clus et al. 2008), particularly in arid climate ecosystems, vapor condensation also reduces crop transpiration $T$ by temporarily creating high-humidity conditions around leaves, thereby reducing the $T$ driving force (Singh et al. 2006; Ben-Asher et al. 2010). Moreover, it also plays a significant role in the water budget of ecosystems and in maintaining the water status of plants in both arid (Jacobs et al. 2002, 2006; Wang and Zhang 2011; Hao et al. 2012; Uclés et al. 2014; Zhang et al. 2015) and humid environments (Liu et al. 2003; Graf et al. 2004; Goldsmith et al. 2013).

Most quantifications of vapor condensation in an agriculture setting have been reported for arid or semiarid areas (Jacobs 1994; Kabela et al. 2009), where it plays an important role in water cycling between the air and the underlying crop canopy surface (Li 2002; Graf et al. 2008; 
Zhang et al. 2015). Dew measurement and dew and plant development have been discussed long ago. Many papers were cited and discussed to illustrate the dew measurement, the links between dew and plant development, and dew forecasting in the research by meteorological scientists like Wallin (1967), who was aware of the agricultural significance of dew and reported that dewfall depths vary widely around the world, reaching as high as $5 \mathrm{~mm} \mathrm{day}^{-1}$ in Brazil. Throughout crop growing seasons, the frequency of occurrence of condensation generally exceeded $50 \%$ of the night periods, with seasonal condensation accounting for $5 \%-20 \%$ of total rainfall over the observation period (Monteith 1961; Jacobs 1994; Wilson et al. 1999; Kabela et al. 2009; Wen et al. 2012; Uclés et al. 2014; Hanisch et al. 2015). Few studies have investigated vapor condensation in rice paddies or wetlands because of the flooding and high humidity associated with these environments. In addition, no studies on vapor condensation over soil can be made in these environments since they are flooded. Luo and Goudriaan (2000) measured the vapor condensation in flooded rice fields in a tropical monsoon region using blotting paper as an absorbent, finding that the maximum daily dew amount was as high as $0.218 \mathrm{~mm}$ (per leaf area). Yan and Xu (2010) found that the maximum monthly vapor condensation measured using a poplar woodstick collector was approximately $1.3 \mathrm{~mm}$ (per leaf area) in September. Moreover, they found that the condensation density could be calculated using regressions with net radiation, ambient dewpoint temperature, the difference between surface and air temperature, and wind speed. In rice fields in Sanjiang Plain, the seasonal vapor condensation (per land surface), assessed by the poplar woodstick collector method, reached 26.2 and $31.4 \mathrm{~mm}$ in 2008 and 2009 , and accounted for $8.68 \%$ and $6.14 \%$ of seasonal precipitation, respectively (Xu et al. 2011).

While previous studies have shown vapor condensation to occur in flooded rice fields, these measurements were made using artificial materials (e.g., absorbent), whereas direct measurements of vapor condensation from real plant and soil surfaces using precise quantification methods (e.g., weighed lysimeter) have never been undertaken. Meanwhile, to cope with increasing water scarcity, several water-saving irrigation (WSI) techniques have been recently applied to rice paddies (Belder et al. 2004; Kato et al. 2011; Rothenberg et al. 2011; Cui and Huang 2012). In WSI rice fields where air humidity is very high and soil is nonflooded during approximately half of the rice growing season, vapor condensation over the interplant soil surface may offset soil evaporation to some degree. Yet, information regarding vapor condensation over either the plant surface or soil surface in WSI rice fields remains unclear, as well as its contribution to crop evapotranspiration.

Several methods have been used to measure the vapor condensation in various ecosystems, including soil or air moisture sensors (Moro et al. 2007; Schmitz and Grant 2009); paper and cloth drosometers (Agam and Berliner 2006; Kabela et al. 2009); artificial condensation plates made from plywood, woodsticks, plastic sheets, or polyethylene plates (Luo and Goudriaan 2000; Liu et al. 2001; Beysens et al. 2005; Ye et al. 2007; Xu et al. 2011); and remote sensing with microwave radiometers (Jackson and Moy 1999; Du et al. 2009). The microlysimeter, designed to directly measure evapotranspiration (ET) or soil evaporation $E$ through mass balance computations (Evett et al. 2012; Uclés et al. 2013), can also be used to measure vapor condensation over the plant surface or interplant soil surface using a water balance equation applied over a given period (Jacobs et al. 2000, 2002; Heusinkveld et al. 2006).

In the present study, custom-designed weighting microlysimeters were installed within a WSI rice field to 1) quantify the amount of vapor condensation over rice plant surfaces or interplant soil surfaces and their contribution to rice $T, E$, or ET and 2) discuss the atmospheric conditions that favored the occurrence of vapor condensation.

\section{Materials and methods}

\section{a. Site and experiment description}

Field measurements were conducted in 2015 by using weighed microlysimeters installed within a WSI rice field at the Kunshan Irrigation and Drainage Experiment Station $\left(31^{\circ} 15^{\prime} 15^{\prime \prime} \mathrm{N}, 120^{\circ} 57^{\prime} 43^{\prime \prime} \mathrm{E}\right)$. The study area, located in the Taihu Lake region of China, has a subtropical monsoon climate. Annual rainfall and annual pan evaporation (type A pan) were estimated as 1097.1 and $1365.9 \mathrm{~mm}$, respectively. Average temperature and relative humidity were $24.8^{\circ} \mathrm{C}$ and $79.2 \%$, respectively, during the rice growing season (July-October). The soil was hydragric anthrosol, with a bulk density of $1.30 \mathrm{~g} \mathrm{~cm}^{-3}$. The soil volumetric saturated moisture $\theta_{s}$, field capacity $\theta_{f}$, and wilting point $\theta_{w}$ values are $0.502,0.392$, and $0.179 \mathrm{~m}^{3} \mathrm{~m}^{-3}$, respectively.

Six weighed microlysimeters were installed in the WSI rice field in 2015 (Fig. 1) and were used to measure hourly $E$ or vapor condensation over soil (Cs) and ET or vapor condensation over both plants and soil $(\mathrm{Cc}+\mathrm{Cs})$ based on the hourly mass change. The six microlysimeters were of two different sizes. Two of the three large microlysimeters were used to calculate ET or Cc + Cs by mass balance, and one was used for load cell calibration. Each 


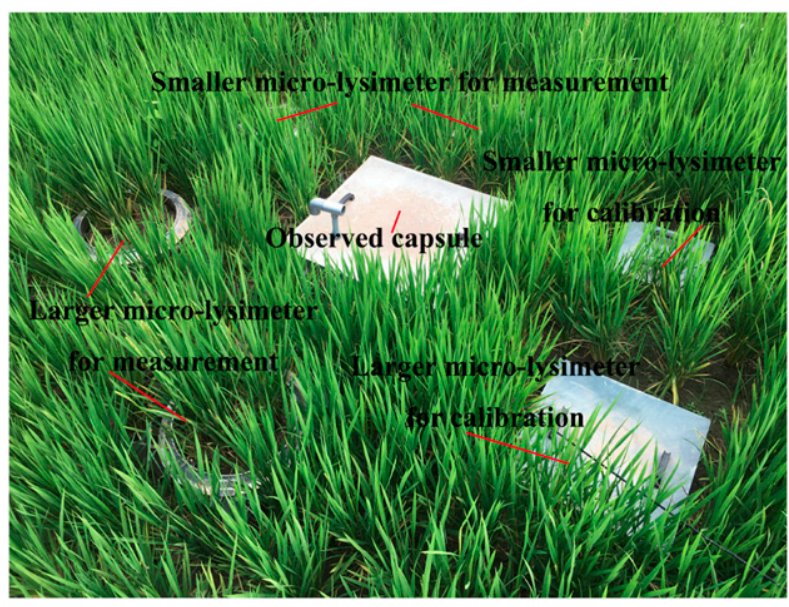

FIG. 1. The setup of the microlysimeter system at the experiment station.

of the large microlysimeters used for mass balance calculation was composed of an inner cylinder (diameter $500 \mathrm{~mm}$; height $500 \mathrm{~mm}$, filled with soil to $400 \mathrm{~mm}$ ), an outer cylinder, weighing system, data recording system, and draining apparatus. The inner cylinders were planted with rice. The inner cylinder was replaced by an object with a fixed weight of $143 \mathrm{~kg}$ in the large microlysimeter used for load cell calibration. The remaining three microlysimeters were small; two were used for mass balance calculation ( $E$ or Cs) without plants in the inner cylinder (diameter $300 \mathrm{~mm}$; height $300 \mathrm{~mm}$, filled with soil to $200 \mathrm{~mm}$ ), and one was used for load cell calibration with an object with a fixed weight of $28 \mathrm{~kg}$. The weights of the inner cylinders or calibration weight object were recorded hourly. Detailed information about the design of the weighed microlysimeters and the field layout can be found in Liu et al. (2018).

Rice was transplanted into both open fields and the lysimeters with plants on 27 June 2015. Seedlings were planted at inter- and intrarow spacings of 0.23 and $0.16 \mathrm{~m}$, respectively, and each lysimeter received four rice plants; the harvest date was 25 October 2015. Cultivation practices including fertilizer and pesticide application followed local practice and were applied to both the microlysimeters and the surrounding fields. Rice was irrigated according to a local WSI practicecontrolled irrigation, either inside the lysimeters or in open rice fields (see Xu et al. 2012). The wetting-drying cycle process in paddy fields under WSI conditions is illustrated in Fig. 2. Excessive water within the inner cylinder was drained through a $1-\mathrm{cm}$ pipe and collected by a graduated cylinder in an observation well to measure its volume. Meteorological data were recorded within the WSI rice field at half-hourly intervals by sensors incorporated in an eddy covariance (EC) system (Open Path Eddy Covariance, Campbell Scientific Inc., United States) installed in the middle of the downwind portion of the field and simultaneously by an automatic meteorological station (WS-STD1, DELTA-T, United Kingdom) over a well-maintained meadow within the experiment station. Net radiation $(\mathrm{Rn})$, air relative humidity (RH), air temperature (Ta), wind speed $V$,

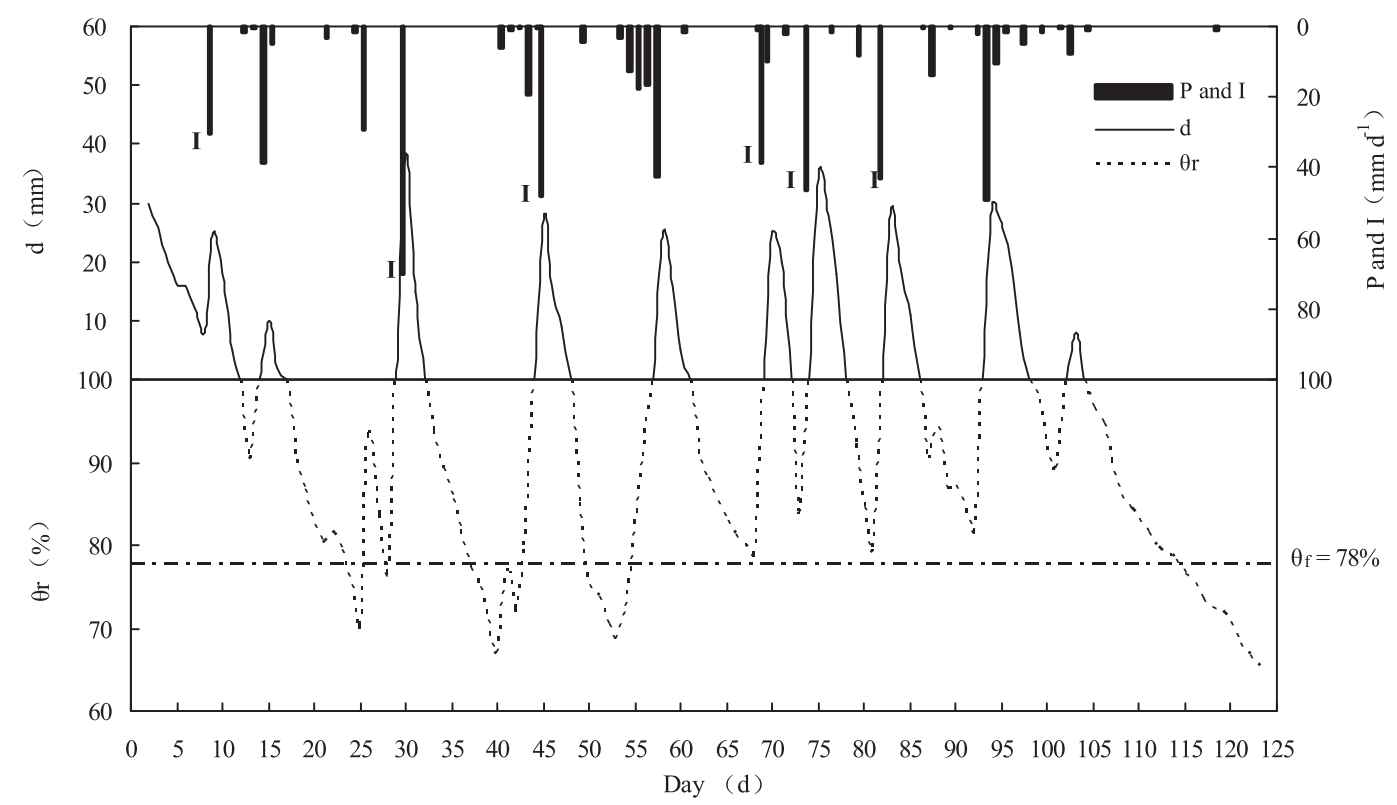

FIG. 2. Variation of soil moisture conditions and corresponding precipitation $P$ and irrigation $I$ under WSI: $\theta_{r}$ represents the relative soil moisture content, $d$ represents the water depth during flooding, and the bar graph without $I$ is precipitation. 


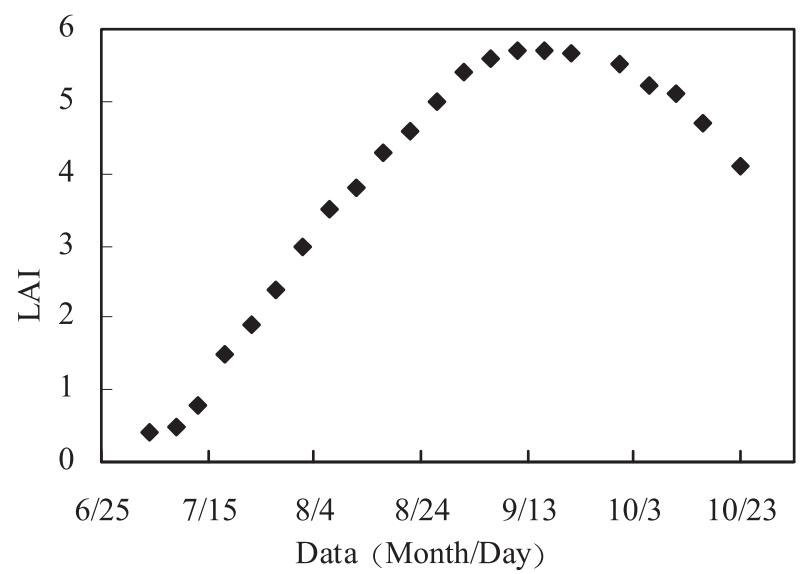

FIG. 3. Time course of measured LAI during the rice growing season in 2015.

atmospheric pressure $(\mathrm{Pa})$, and precipitation $P$ were measured using both instruments. The Rn, RH, Ta, and $V$ were measured at 1.5, 2.0, 2.0, and $2.5 \mathrm{~m}$ above ground surface, respectively. Simultaneously, canopy temperature (Tc), dewpoint temperature (Td) at a height of $2.0 \mathrm{~m}$, soil temperature (Ts), and volumetric soil moisture content $\theta$ (at 0.10-, 0.20-, and 0.30-m depths) were recorded in the WSI rice field by EC system sensors. The volumetric soil moisture content $\theta$ was also routinely monitored daily (0800 LT) both inside and outside the microlysimeter by time domain reflectometry (TRASE System, Soil Moisture Equipment Corporation, United States) at $0-0.2-, 0.1-0.3-$, and $0.2-0.4-\mathrm{m}$ depths. The soil surface temperature $\left(\mathrm{Ts}_{-0}\right)$ was calculated using a harmonic method (Horton et al. 1983; Horton and Wierenga 1983) based on Ts measured at a depth of $0.10 \mathrm{~m}$. The leaf area index (LAI), which influences Cc rates, was measured for five fixed plants over the full growing seasons (Fig. 3). The LAI for the days intervening between measurements was determined by linear interpolation.

\section{b. Climatic conditions}

Climatic conditions are enumerated in Table 1. In 2015, the annual rainfall $P$, maximum air temperature
(Ta,max), minimum air temperature (Ta,min), and actual mean vapor pressure (VP) were $1067.3 \mathrm{~mm} \mathrm{yr}^{-1}$, $20.36^{\circ} \mathrm{C}, 13.39^{\circ} \mathrm{C}$, and $1.73 \mathrm{kPa}$, respectively, closely matching the 50-yr average (1965-2014). The mean values of Ta,max and Ta,min from July to October 2015, namely $28.38^{\circ}$ and $21.98^{\circ} \mathrm{C}$, respectively, were also near the 50-yr average. Rainfall during the 2015 rice season was $327.6 \mathrm{~mm}$, slightly less than the 50 -yr mean $(398.9 \mathrm{~mm})$. Because the measured climatic conditions during the 2015 rice season are representative of this region, the results concerning vapor condensation should also be representative of this region.

\section{c. Mass balance calculation for microlysimeters}

Evapotranspiration, evaporation, and vapor condensation were estimated by hourly mass balance calculations for the bottom-sealed microlysimeters (Evett et al. 2012). Assuming that nocturnal condensation never occurred simultaneously with evaporation or evapotranspiration, and ignoring the vapor condensation during the hours with irrigation, drainage, or precipitation events, the absolute value of hourly mass loss $\Delta M$ was equal to ET $(\Delta M>0)$ or $\mathrm{Cs}+\mathrm{Cc}(\Delta M<0)$ in lysimeters with plants, and equal to $E(\Delta M>0)$ or Cs $(\Delta M<0$, including the soil hygroscopic water) in lysimeters without plants (Allen et al. 1998; Heusinkveld et al. 2006; Ding et al. 2010). All values of the mass balance calculation were the average of the two microlysimeters with or without plants.

\section{d. Contribution of vapor condensation to evapotranspiration}

In the present study, the absolute value of positive hourly mass loss $\Delta M$ was deemed to represent ET or $E$, while the absolute value of negative $\Delta M$ represented $\mathrm{Cs}+\mathrm{Cc}$ or Cs. Yet, the water or mass balance was primarily calculated daily in the field, overlooking the occurrence of vapor condensation. The contributions of vapor condensation to rice ET or $E$ were evaluated daily. Daily vapor condensation rates were calculated as the sum of hourly vapor condensation rates, and daily $E, T(T=\mathrm{ET}-E)$, and ET were calculated as the sum of hourly $E, T$, and ET. The contributions of daily vapor

TABLE 1. Climatic conditions during 50 years from 1965 to 2014 and in 2015.

\begin{tabular}{|c|c|c|c|c|c|c|}
\hline & \multicolumn{2}{|c|}{ Annual } & \multicolumn{4}{|c|}{ Rice season } \\
\hline & \multirow{2}{*}{$\frac{1965-2014}{\text { Mean }}$} & \multirow{2}{*}{$\frac{2015}{\text { Mean }}$} & \multicolumn{3}{|c|}{ 1965-2014 } & \multirow{2}{*}{$\frac{2015}{\text { Mean }}$} \\
\hline & & & Mean & Max & Min & \\
\hline $\mathrm{Ta}, \max \left({ }^{\circ} \mathrm{C}\right)$ & 20.19 & 20.36 & 28.48 & 30.86 & 26.11 & 28.38 \\
\hline $\mathrm{Ta}, \min \left({ }^{\circ} \mathrm{C}\right)$ & 13.35 & 13.39 & 21.73 & 23.28 & 20.33 & 21.98 \\
\hline $\mathrm{VP}(\mathrm{kPa})$ & 1.76 & 1.73 & 2.68 & 2.8 & 2.43 & 2.57 \\
\hline$P(\mathrm{~mm})$ & 1156.8 & 1067.3 & 398.9 & 896.5 & 115.4 & 327.6 \\
\hline
\end{tabular}


condensation to evapotranspiration, namely, contributions of $\mathrm{Cc}$ to $T$, Cs to $E$, and $\mathrm{Cc}+\mathrm{Cs}$ to $\mathrm{ET}$, were calculated. To reveal the impact of vapor condensation on the water budget in the WSI rice field, daily ET or $E$ ignoring vapor condensation and revolatilization were calculated as the sum of hourly mass change $\Delta M$ (including both positive values as ET or $E$ and negative values as $\mathrm{Cc}+\mathrm{Cs}$ or $\mathrm{Cs}$ ) and were referred to as $\mathrm{ET}^{*}$ and $E^{*}\left(T^{*}=\mathrm{ET}^{*}-E^{*}\right)$, respectively. Thus, ET was the total water loss and equaled $\mathrm{ET}^{*}$ plus the condensed water that was evaporated again in the morning hours. The relationship and difference between ET and $\mathrm{ET}^{*}$ is shown in Fig. 4. It shows a simplified midnight-tomidnight time course of total weight.

\section{e. Occurrence conditions and frequency analysis}

Times of Cc and Cs occurrence data served in calculating their frequency of occurrence and identifying the conditions of occurrence of vapor condensation. The dataset included the measured values of $\mathrm{RH}$, wind speed $V$, Ta, Tc, ambient Td, and Ts. Differences in Tc - Td or $\mathrm{Tc}-\mathrm{Ta}$ were analyzed when determining the criteria of Cc occurrence, while differences in $\mathrm{Ts}_{-0}-\mathrm{Td}$ or $\mathrm{Ts}_{-0}-\mathrm{Ta}$ were analyzed when discussing the criteria of Cs occurrence. For each variable included in the occurrence condition analysis, values were ranked by $\mathrm{Cc}$ or $\mathrm{Cs}$ values and divided into different subsets.

Frequency distributions of $\mathrm{Cc}$ or Cs occurrence were analyzed either at different condensation rates or during different hours of the day. For a specific meteorological condition, the possibility of $\mathrm{Cc}$ or Cs occurrence for a specific range of meteorological conditions was calculated as a ratio of the number of data with $\mathrm{Cc}$ or $\mathrm{Cs}$ actual occurrence to possible times (including both occurrence and nonoccurrence times) under a specific range of meteorological condition during the rice season.

\section{Results}

\section{a. Occurrence of vapor condensation in WSI rice fields}

In the WSI rice field during the 2015 rice season period, there occurred 65 days without rainfall and irrigation events. Over the growing season, vapor condensation over plant surfaces was reported for $586 \mathrm{~h}$, occurring within 60 of the 65 individual days monitored, while vapor condensation over interplant soil surfaces occurred for $98 \mathrm{~h}$ within 33 individual days. Frequency analysis indicated that the hourly $\mathrm{Cc}$ rates varied from 0.002 to $0.305 \mathrm{~mm} \mathrm{~h}^{-1}$, but were less than $0.08 \mathrm{~mm} \mathrm{~h}^{-1}$ in most occurrences (Fig. 5a). The Cc events occurred overnight from sunset (1600 LT) to sunrise (0800 LT),

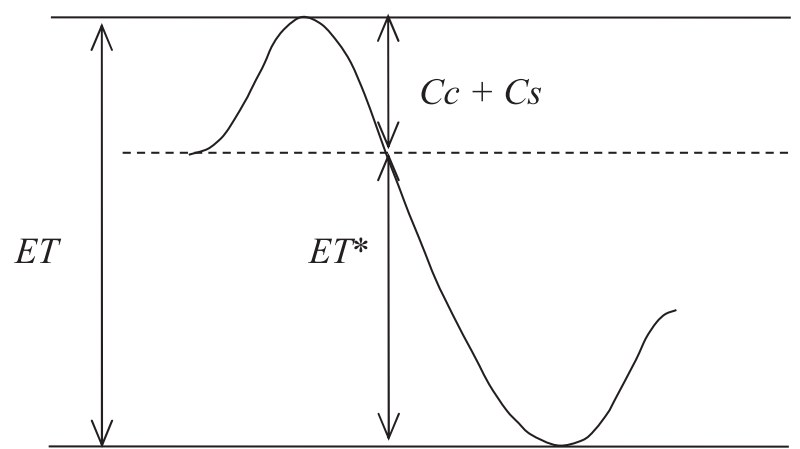

FIG. 4. Schematic diagram of the relationship between ET and $\mathrm{ET}^{*}$.

mostly between 2100 and 0600 LT. Hence, the daily timeframe for $\mathrm{Cc}$ occurrence was $16 \mathrm{~h}$ (i.e., $8 \mathrm{~h} \mathrm{day}^{-1}$ were dew-free), which concurred with the results of studies examining upland fields (Malek et al. 1999; Kabela et al. 2009) and sparse grass vegetation (Hanisch et al. 2015). The frequency distribution of Cc occurrence by hour of the day and Cc rates by hour of the day varied similarly (Fig. 5b), achieving a maximum of $12.5 \%$ for frequency of occurrence at $0400-0500 \mathrm{LT}$ and a concurrent maximum rate of $0.096 \mathrm{~mm} \mathrm{~h}^{-1}$.

The soil surface beneath the rice canopy exhibited hourly Cs rates varying from 0.004 to $0.139 \mathrm{~mm} \mathrm{~h}^{-1}$ (Fig. 6a), with over $70 \%$ of occurrences falling within the range of $0.01-0.03 \mathrm{~mm} \mathrm{~h}^{-1}$. The frequency distribution of Cs occurrences over the hours of the day and the Cs rate also varied in a similar pattern (Fig. 6b), though both differed in magnitude from values for Cc. The time frame for Cs occurrence time was from 0100 to $1100 \mathrm{LT}$, with the greatest occurrence between 0600 and 0800 LT. A 10-h stretch of Cs occurrence is longer than that reported by Verhoef et al. (2006) over bare soil in an olive grove, but shorter than that reported by Zhang et al. (2015) over farmland in a semiarid region. Both the occurrence frequency and average Cs rates increased suddenly around sunrise and reached their maximums (21.6\% and $0.044 \mathrm{~mm} \mathrm{~h}^{-1}$, respectively) between 0700 and $0800 \mathrm{LT}$. This might be explained by the vapor condensation rates over soil incorporating the amount of hygroscopic water by soil after sunrise (Verhoef et al. 2006; Zhang et al. 2015), which occurs when Ts $>$ Td and the RH of the soil's pores is lower than that of the air (Agam and Berliner 2006).

\section{b. Diurnal pattern of hourly vapor condensation in different rice growth stages}

Drawing on data on the diurnal pattern of hourly vapor condensation rates over four consecutive rainfree days in each month from July to October 2015, the diurnal variation of $\mathrm{Cc}$ and $\mathrm{Cs}$, together with the 

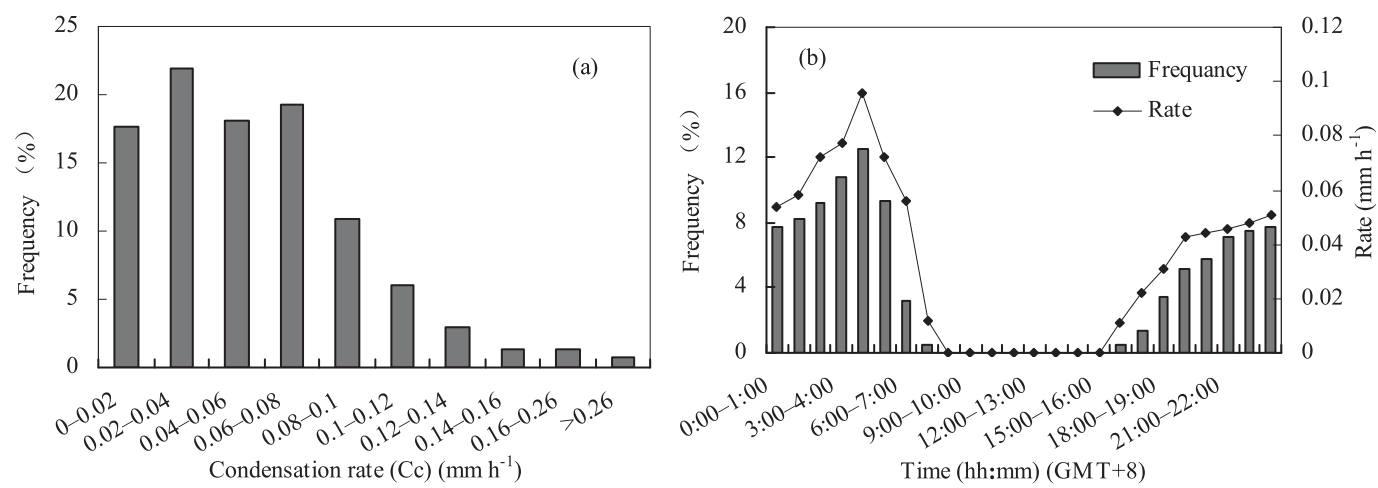

FIG. 5. Frequency distribution of (a) Cc and (b) condensation over the hour of the day.

surface to dewpoint temperature difference $(\mathrm{Tc}-\mathrm{Td}$, or $\mathrm{Ts}_{-0}-\mathrm{Td}$ ) were plotted (Figs. 7, 8).

The value of the difference of Tc $-\mathrm{Td}$ varied diurnally in a unimodal bell shape, with negative values at night. The range in Tc - Td for typical days in July, August, September, and October were from $-0.22^{\circ}$ to $11.84^{\circ} \mathrm{C}$, from $-0.77^{\circ}$ to $8.02^{\circ} \mathrm{C}$, from $-1.11^{\circ}$ to $12.46^{\circ} \mathrm{C}$, and from $-2.16^{\circ}$ to $13.14^{\circ} \mathrm{C}$, respectively, while the mean daily $\mathrm{Cc}$ rates for these months were $0.283,0.334$, 0.772 , and $0.670 \mathrm{~mm} \mathrm{day}^{-1}$, while Cc durations were 5.8, $7.8,11.5$, and $10.3 \mathrm{~h} \mathrm{day}^{-1}$. Vapor condensation over rice plants has generally been found to occur at night (Kalthoff et al. 2006; Zhang et al. 2015), when Tc $<$ Td (Fig. 7). In the present case it also occasionally occurred when Tc - Td dropped suddenly, even if Tc $>$ Td. For example, Cc occurred when the value of Tc - Td was near or smaller than $0^{\circ} \mathrm{C}$ (e.g., 0200-0600 LT 26 July, 0400 LT 27 July, 0300-0600 LT 28 July, and 0500 LT 29 July), or during a sudden drop in Tc - Td (e.g., 2000 LT 26 July, 2000 LT 27 July, 1900-2000 LT 28 July, and 1900-2200 LT 29 July). The number of hours in August when $\mathrm{Tc}-\mathrm{Td}<0^{\circ} \mathrm{C}$ was greater than in July, as was the frequently of occurrence of Cc events. In September and October, the negative amplitude of $\mathrm{Tc}-\mathrm{Td}$ was greater than that in July and August, and the duration of periods of nocturnal negative $\mathrm{Tc}-\mathrm{Td}$ values was prolonged. The hourly $\mathrm{Cc}$ rates and frequency of $\mathrm{Cc}$ occurrence in these fall months were highest between 0600 and 1100 LT.

For Cs events (Fig. 8), both hourly Cs rates and their frequency of occurrence were much lower than for $\mathrm{Cc}$ events. In June, the LAI and canopy cover ratios were low; the soil beneath the rice canopy received more solar radiation during the day, which resulted in soil heating. In addition, the difference of $\mathrm{Ts}_{-0}-\mathrm{Td}$ varied from $1.69^{\circ}$ to $12.65^{\circ} \mathrm{C}$, (i.e., $\mathrm{Ts}_{-0}>\mathrm{Td}$ ); as a result, no Cs event occurred. On typical days in August-October, $\mathrm{Ts}_{-0}>\mathrm{Td}$, while condensation over soil occurred occasionally. In August (Fig. 8a), Cs rates were low and occurred between 0300 and 0600 LT occasionally. The Cs rates then increased in September, and the occurrence time was slightly delayed (0400-0800 LT; Fig. 8b). The rates and the frequency of occurrence of Cs increased further in October (Fig. 8c), with an average daily amount of $0.152 \mathrm{~mm} \mathrm{day}^{-1}$, which primarily occurred from 0600 to $1100 \mathrm{LT}$. Differences in $\theta$ might have led to the difference in Cs rates between August and September-October. On typical days in August [days after transplanting (DAT) $=62-65$ days] and September (DAT $=74-77$ days), $\theta_{r}>85 \%$ (as listed in Fig. 2), and the Cs rates were low. Yet, in October
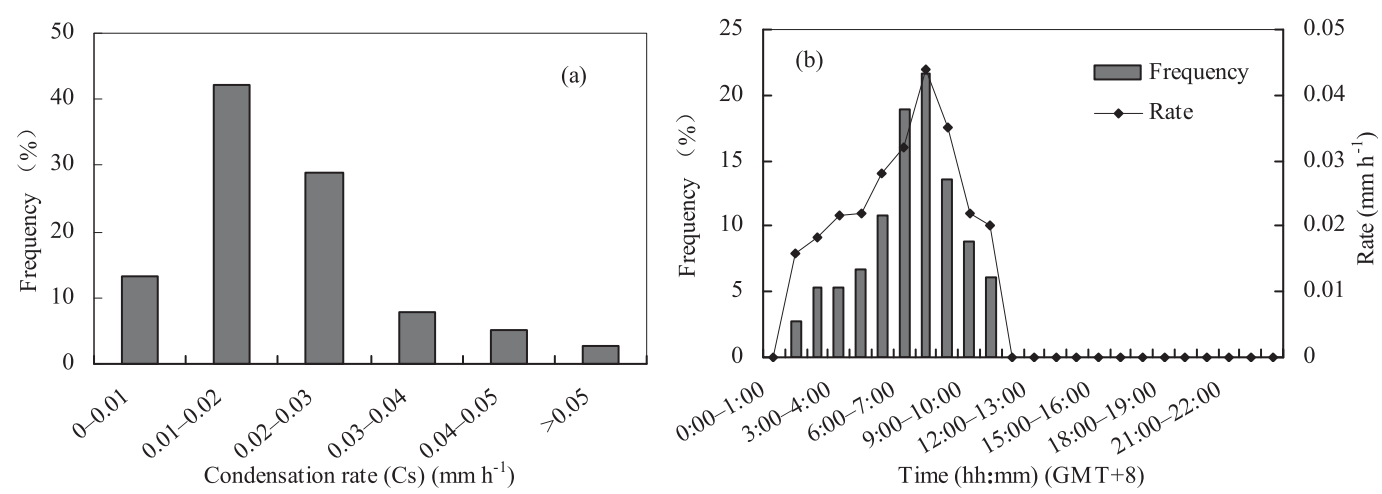

FIG. 6. Frequency distribution of (a) Cs and (b) condensation over the hour of the day. 

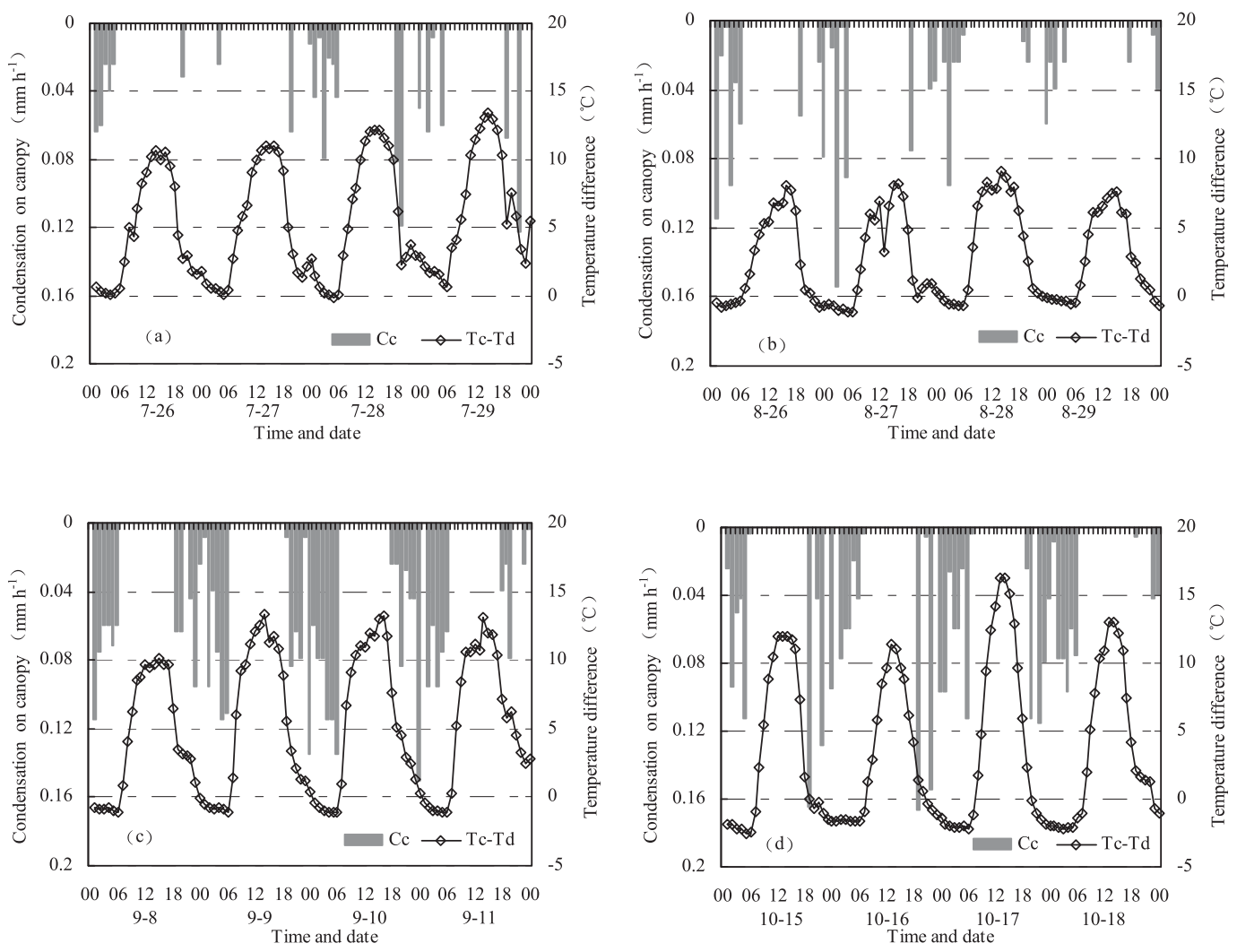

FIG. 7. Diurnal variation of hourly Cc and the corresponding temperature difference between Tc and Td in (a) July,

(b) August, (c) September, and (d) October.

$(\mathrm{DAT}=111-114$ days $), \theta_{r}$ was relatively low, and the Cs rates were much higher.

\section{c. Seasonal variation of daily vapor condensation}

The daily vapor condensation rates of $\mathrm{Cc}$ and $\mathrm{Cs}$ in the WSI rice field during the rice season are shown in Fig. 9. In the WSI rice field, Cc events occurred in 60 out of the 65 rainless days $(92.3 \%$ ), while Cs events occurred in 33 of the 65 days $(50.8 \%)$. Daily $\mathrm{Cc}$ and Cs rates varied from 0.086 to $1.128 \mathrm{~mm} \mathrm{day}^{-1}$ and from 0.020 to $0.178 \mathrm{~mm} \mathrm{day}^{-1}$, respectively, with seasonal totals of 32.276 and $3.132 \mathrm{~mm}$, respectively. Over the season's 65 rain-free days, the daily $\mathrm{Cc}+\mathrm{Cs}$ rate was $0.545 \mathrm{~mm} \mathrm{day}^{-1}$, with a maximum value of $1.227 \mathrm{~mm} \mathrm{day}^{-1}$ on 12 October 2015. These $\mathrm{Cc}+\mathrm{Cs}$ rates were much greater than those reported for grasslands and sparse shrubs (0.1-0.2 $\mathrm{mm}$ day $^{-1}$; Jacobs et al. 2006; Moro et al. 2007), and the Cc rates were much higher than those reported under corn $(0.01-0.6 \mathrm{~mm})$ and soybean $\left(0.003-0.8 \mathrm{~mm} \mathrm{day}^{-1}\right)$ cultivation in arid and semiarid environments (Kabela et al. 2009).

As in the study of Zhang et al. (2015), in the present study of a WSI rice field, daily Cc rates and frequencies of occurrence in the fall (September and October) were greater than those in the summer (July and August). Besides the difference in micrometeorological conditions between midsummer and fall, the larger late season leaf area for condensation to occur on likely also contributed to the greater $\mathrm{Cc}$ rates in September and October. The $\mathrm{Cc}+\mathrm{Cs}$ rate was greatest at the yellow ripening stage, ranging from 0.555 to $1.227 \mathrm{~mm} \mathrm{day}^{-1}$, with an average of $0.873 \mathrm{~mm}$ day $^{-1}$. The frequency of Cs events in the WSI rice field was very low in July and August and increased gradually in the fall, reaching its maximum frequency in late October. Apart from climatic conditions, this phenomenon might be ascribed to generally low $\theta\left(\theta<\theta_{f}\right.$; Fig. 2$)$ at the yellow ripening stage, which favored the occurrence of soil hygroscopic water in the early morning under high $\mathrm{RH}$ (generally $>95 \%$ ).

\section{d. Contribution of vapor condensation to rice evapotranspiration}

The daily ET, $T$, and $E$, as well as the contributions of $\mathrm{Cc}, \mathrm{Cs}$, and $\mathrm{Cc}+\mathrm{Cs}$ to $T, E$, and $\mathrm{ET}$, were assessed in WSI paddy fields (Fig. 10). On days when condensation occurred, $\mathrm{Cc} / T, \mathrm{Cs} / E$, and $(\mathrm{Cc}+\mathrm{Cs}) / \mathrm{ET}$ averaged 0.142 , 0.220 , and 0.116 , respectively, with maximum values of 

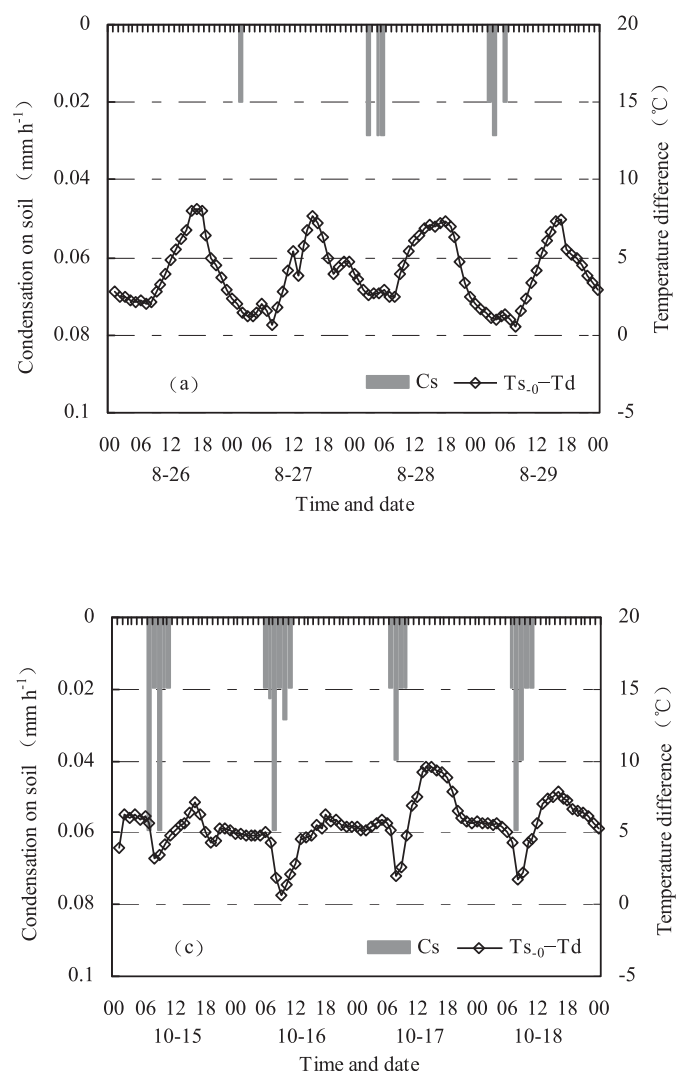

0.309 (12 October), 0.368 (14 October), and 0.276 (12 October), respectively, which appeared during the yellow maturity stage. Seasonal Cc, Cs, and $\mathrm{Cc}+\mathrm{Cs}$ were estimated as $32.3,3.1$, and $35.4 \mathrm{~mm}$, and their contributions to seasonal $T, E$, or ET were $9.6 \%, 1.6 \%$, and $6.7 \%$, respectively.

At the tillering stage (from 7 July to 7 August), ET and $T$ increased gradually, reaching their respective maxima in the late tillering stage, when the contributions of vapor condensation were minimal. The contribution of $\mathrm{Cs} / E$ at

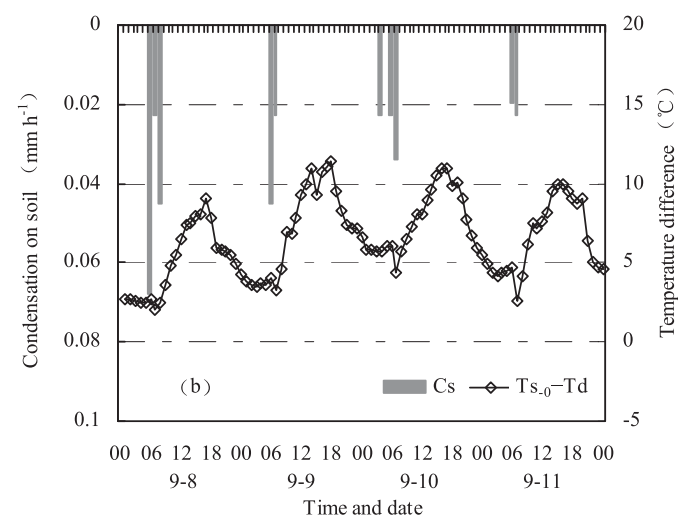

FIG. 8. Diurnal variation of hourly Cs and the corresponding temperature difference between $\mathrm{Ts}_{-0}$ and $\mathrm{Td}$ in (a) August, (b) September, and (c) October. this stage was close to zero, as Cs was undetectable on days preceding 15 July 2015 . The $\mathrm{Cc} / \mathrm{T}$ and $(\mathrm{Cc}+\mathrm{Cs}) / \mathrm{ET}$ varied from 0 to 0.1 , with respective mean values of 0.085 and 0.045 . During the period from jointing to flowering (from 8 August to 12 September 2015), Cc/T and $(\mathrm{Cc}+\mathrm{Cs}) / \mathrm{ET}$ increased with the increase in LAI. The value of $\mathrm{Cc} / T$ was 0.120 at jointing-booting and 0.149 at heading-flowering, while equivalent $(\mathrm{Cc}+\mathrm{Cs}) / \mathrm{ET}$ values were 0.092 and 0.126 , respectively. The Cs events occurred more frequently in this stage, yet its

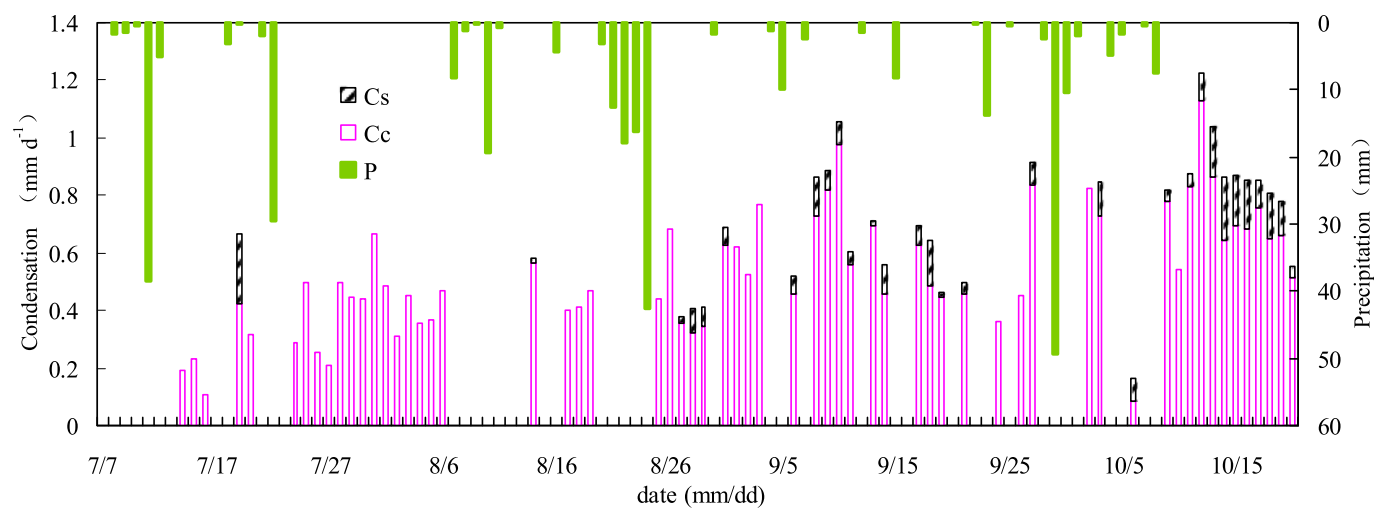

FIG. 9. Daily Cc and Cs in the WSI rice field ( $P$ represents precipitation). 


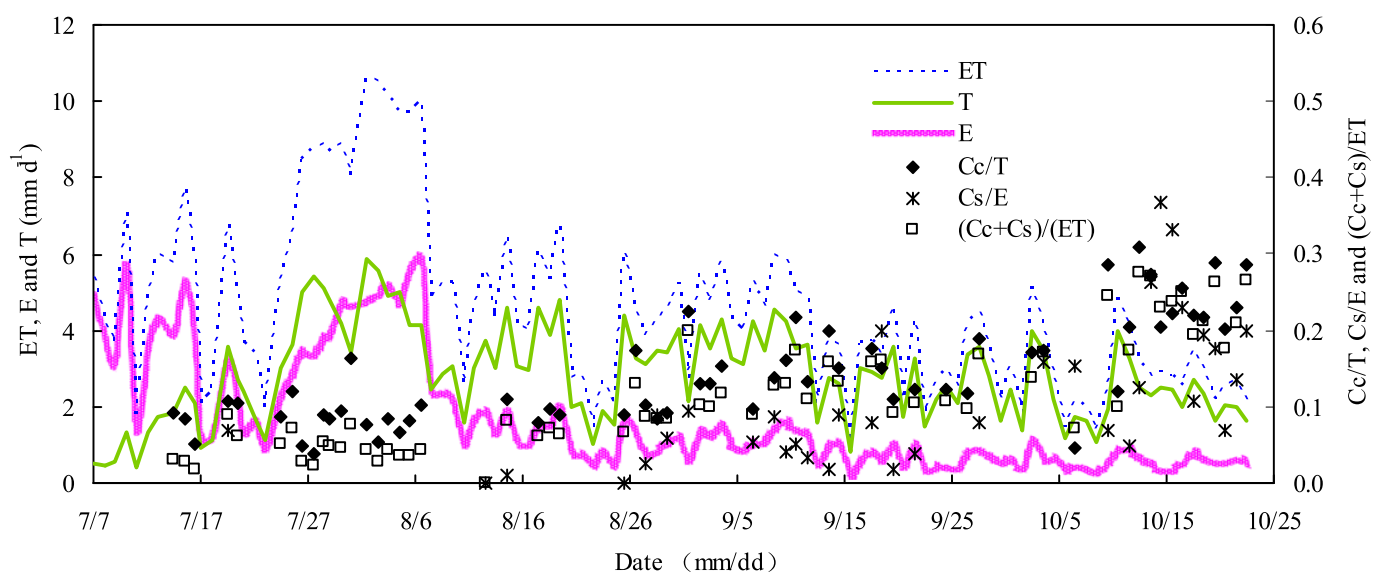

FIG. 10. Soil evaporation $E$, rice transpiration $T$, and ET, as well as the contribution of vapor condensation to $E, T$, and $\mathrm{ET}$ (Cc to $T$, Cs to $E$, and $\mathrm{Cc}+\mathrm{Cs}$ to ET) during the rice growing season in 2015.

contributions to $E$ fluctuated greatly. During the milk period (from 13 September to 11 October), $T, E$, and the ratios of $\mathrm{Cc} / T$ and $\mathrm{Cs} / E$ varied less remarkably with mean values of $\mathrm{Cc} / T, \mathrm{Cs} / E$, and $(\mathrm{Cc}+\mathrm{Cs}) / \mathrm{ET}$ of 0.156 , 0.087 , and 0.139 , respectively. During the yellow maturity stage (12-22 October), the amount of condensation was large, whereas $T, E$, and ET were small. Thus, contributions of $\mathrm{Cc} / T, \mathrm{Cs} / E$, and $(\mathrm{Cc}+\mathrm{Cs}) / \mathrm{ET}$ were much greater than in prior stages, with average values of $0.246,0.199$, and 0.235 , respectively.

\section{e. Condensation occurrence conditions}

Many meteorological factors influence the formation and amount of vapor condensation, including the surface and air temperatures, relative humidity, and wind speed. Among these factors, the values of Tc - Ta and Ts - Ta, RH, and wind speed $V$ were essential factors that dominated the formation of dewfall and hygroscopic water (Figs. 11, 12).

Theoretically, Cc occurs only when Tc declines below Ta or Td. As expected, Cc occurred when Tc $-\mathrm{Ta}<$ $0^{\circ} \mathrm{C}$, and the probability of occurrence of Cc was nearly $100 \%$ when $\mathrm{Tc}-\mathrm{Ta}<-4^{\circ} \mathrm{C}$ (Fig. 11b). Regarding the temperature difference of $\mathrm{Tc}-\mathrm{Td}, \mathrm{Cc}$ always occurred as expected when $\mathrm{Tc}-\mathrm{Td}<0^{\circ} \mathrm{C}$. Furthermore, $\mathrm{Cc}$ occurred with a considerable probability even when $\mathrm{Tc}-\mathrm{Td}>0{ }^{\circ} \mathrm{C}$. For example, for approximately $47.3 \%$ and $44.4 \%$ of $\mathrm{Cc}$ occurrences when $0^{\circ} \mathrm{C}<\mathrm{Tc}-\mathrm{Td}<$ $1.5^{\circ}$ and $1.5^{\circ} \mathrm{C}<\mathrm{Tc}-\mathrm{Td}<3.0^{\circ} \mathrm{C}$, respectively, Cc also occasionally occurred when $\mathrm{Tc}-\mathrm{Td}>3^{\circ} \mathrm{C}$ (Fig. 11a). This was attributable to the fact that $\mathrm{Ta}$ and $\mathrm{Td}$ were measured $2 \mathrm{~m}$ above the soil surface, which was above the rice canopy. The dewpoint at canopy height (typically less than $1.2 \mathrm{~m}$ ) might be higher than at $2 \mathrm{~m}$, and the $\mathrm{Tc}-\mathrm{Td}$, calculated based on Td measured at $2 \mathrm{~m}$ might have overestimated the actual temperature difference between the canopy and its nearest ambient air.

High ambient $\mathrm{RH}$ and low $V$ favored the occurrence of vapor condensation. With $\mathrm{RH}$ above $60 \%$ in the subtropical monsoon climate of East China, the occurrence of a Cc event was more likely at an increased $\mathrm{RH}$ (Fig. 11c). The probability of a Cc occurrence exceeded $50 \%$ when $\mathrm{RH}>80 \%$ and peaked at $70 \%$ when $\mathrm{RH}>$ $90 \%$. For $V$, the probability of Cc occurrence was greater than $50 \%$ when $V<0.45 \mathrm{~m} \mathrm{~s}^{-1}$ and decreased sharply to approximately $15 \%$ when $V>0.6 \mathrm{~m} \mathrm{~s}^{-1}$ (Fig. 11d). Notably, in the current experiment the $V$ and RH were measured at heights of 2.5 and $2 \mathrm{~m}$, respectively. Since $V$ generally increased and $\mathrm{RH}$ decreased with increasing elevation, $V$ was generally higher at $2.5 \mathrm{~m}$ and $\mathrm{RH}$ was generally lower at $2 \mathrm{~m}$ than their corresponding variables within the rice canopy (Uclés et al. 2014; Hanisch et al. 2015). This suggests that the threshold for Cc occurrence was higher for RH and lower for $V$ at leaf level than for those above the plant canopy.

The conditions for the occurrence of Cs differ slightly from those for Cc: Cs occurred predominantly when $\mathrm{Ta}>\mathrm{Ts}_{-0}$, and occasionally when $\mathrm{Ta}<\mathrm{Ts}_{-0}$, for certain ranges of $-4.5^{\circ} \mathrm{C}<\mathrm{Ts}_{-0}-\mathrm{Ta}<3^{\circ} \mathrm{C}$. The greatest potential for occurrence existed when $-4.5^{\circ} \mathrm{C}<$ $\mathrm{Ts}_{-0}-\mathrm{Ta}<-3^{\circ} \mathrm{C}$, declining as $\mathrm{Ts}_{-0}-\mathrm{Ta}$ increased (Fig. 12b). In the present study, Cs generally occurred when $\mathrm{Ts}_{-0}-\mathrm{Td}>0^{\circ} \mathrm{C}$, with the highest probability occurring when $0^{\circ} \mathrm{C}<\mathrm{Ts}_{-0}-\mathrm{Td}<2^{\circ} \mathrm{C}$, and a roughly $50 \%$ occurrence for $2^{\circ} \mathrm{C}<\mathrm{Ts}_{-0}-\mathrm{Td}<5^{\circ} \mathrm{C}$. As with Cc, the instances of Cs occurred under high ambient $\mathrm{RH}$ and low $V$. The possibility of Cs occurrence increased as $\mathrm{RH}$ increased, with a maximum probability of occurrence $(20 \%$ ) when $\mathrm{RH}>90 \%$ (Fig. $12 \mathrm{c}$ ), compared to a 

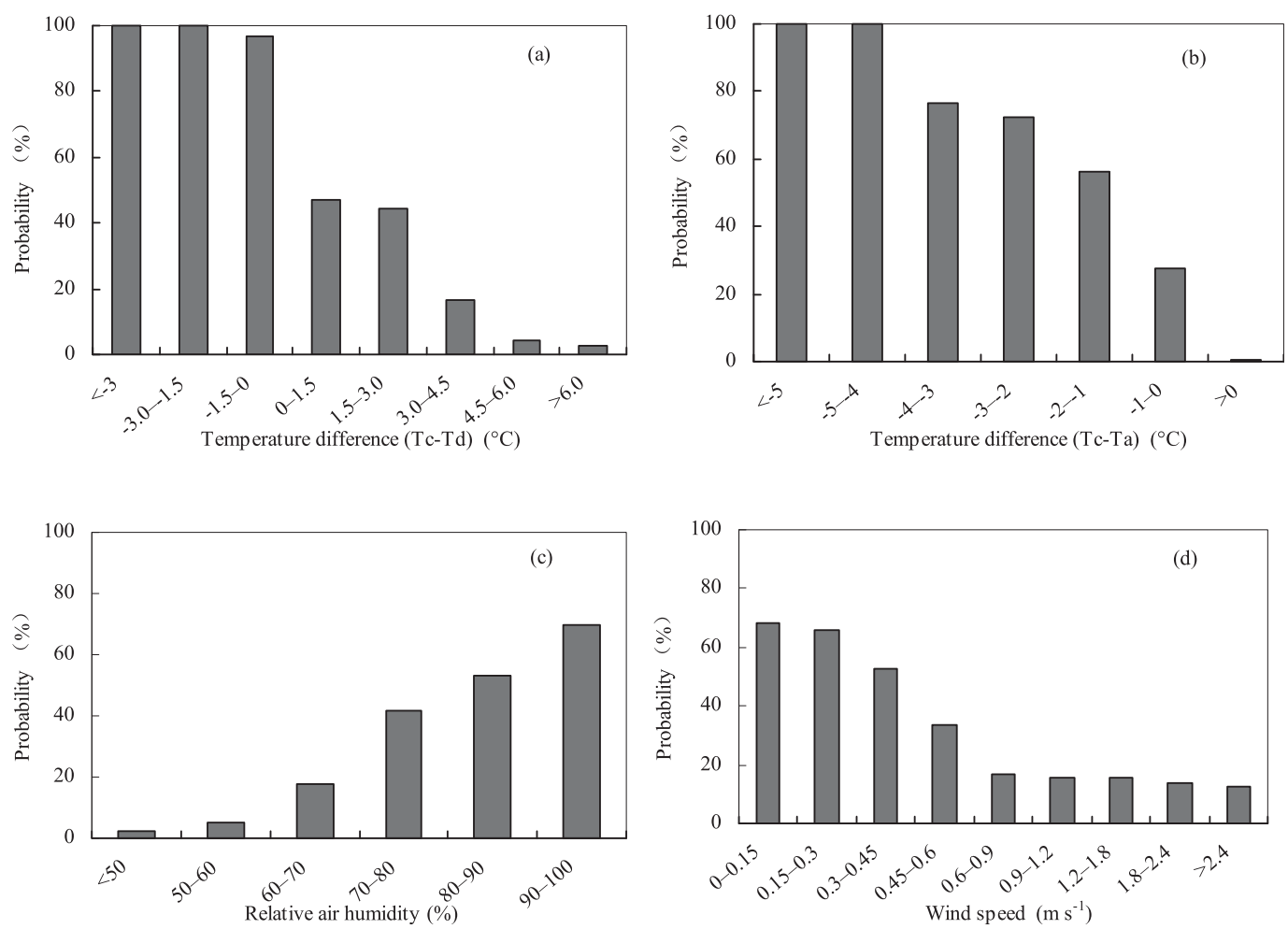

FIG. 11. Probability of leaf condensation occurrence with meteorological conditions (a) Tc - Td, (b) Tc - Ta, (c) RH, and (d) wind speed $V$.

lesser than $10 \%$ probability when $\mathrm{RH}<90 \%$. Regarding wind speed (Fig. 12d), the probability of Cs occurrence was relatively high when the wind speed at $2.5 \mathrm{~m}$ was between 0 and $0.3 \mathrm{~m} \mathrm{~s}^{-1}$, decreasing as $V$ increased, and becoming evenly distributed among the $V$ ranges of $0.75-1.6 \mathrm{~m} \mathrm{~s}^{-1}$.

In contrast to the possibility of Cc occurrence under temperature conditions (Fig. 11b), Cs occurred in a greater proportion under the conditions where either $\mathrm{Ts}_{-0}-\mathrm{Td}$ or $\mathrm{Ts}_{-0}-\mathrm{Ta}$ exceeded zero (Fig. 12b). The value of $\mathrm{Ts}_{-0}$ is not only sensitive to Ta, but also to the soil heat flux, whether it is heat storage or release. Included in Cs, soil hygroscopic water differs according to the conditions under which dewfall occurs over the soil surface. Compared to dewfall, soil hygroscopic water generally existed at an even wider range of temperature conditions (Verhoef et al. 2006; Zhang et al. 2015). Thus, the relationship between $\mathrm{Ts}_{-0}$ and $\mathrm{Ta}$ or $\mathrm{Td}$ affects vapor condensation in a complex manner. The greater the RH and the lower the $V$, the easier it becomes for vapor condensation to occur, though the possibility of occurrence of Cs is less than that of Cc under the same conditions. Since the selected year experienced conventional meteorological conditions, these conclusions should generally be universal and representative for the region under water-saving irrigation.

\section{Discussion}

\section{a. Methods for measuring vapor condensation in paddy fields}

Past measurements of vapor condensation onto rice leaves has been undertaken with artificial absorbents such as blotting paper (Luo and Goudriaan 2000) or woodsticks (Yan et al. 2010). However, hairs on either side of rice leaves favor the formation of water droplets, such that $\mathrm{Cc}$ measured using artificial absorbents likely underestimates the real Cc. Because of the flooding conditions in traditional rice paddy cultivation, one cannot distinguish condensation over soil from hygroscopic water from soil. The present study was the first attempt to measure vapor condensation over rice and soil (including soil hygroscopic water) separately. By using high-precision-weighed microlysimeters, the actual amount of condensation onto rice plants and soil was measured separately and directly in WSI rice fields. This method is therefore more suitable for paddy fields than those reported previously.

In the current study, to ensure the accuracy of microlysimeter measurements, the soil depth in the microlysimeters extended to $0.40 \mathrm{~m}$, which was chosen as it matched the maximum root length of rice. In 

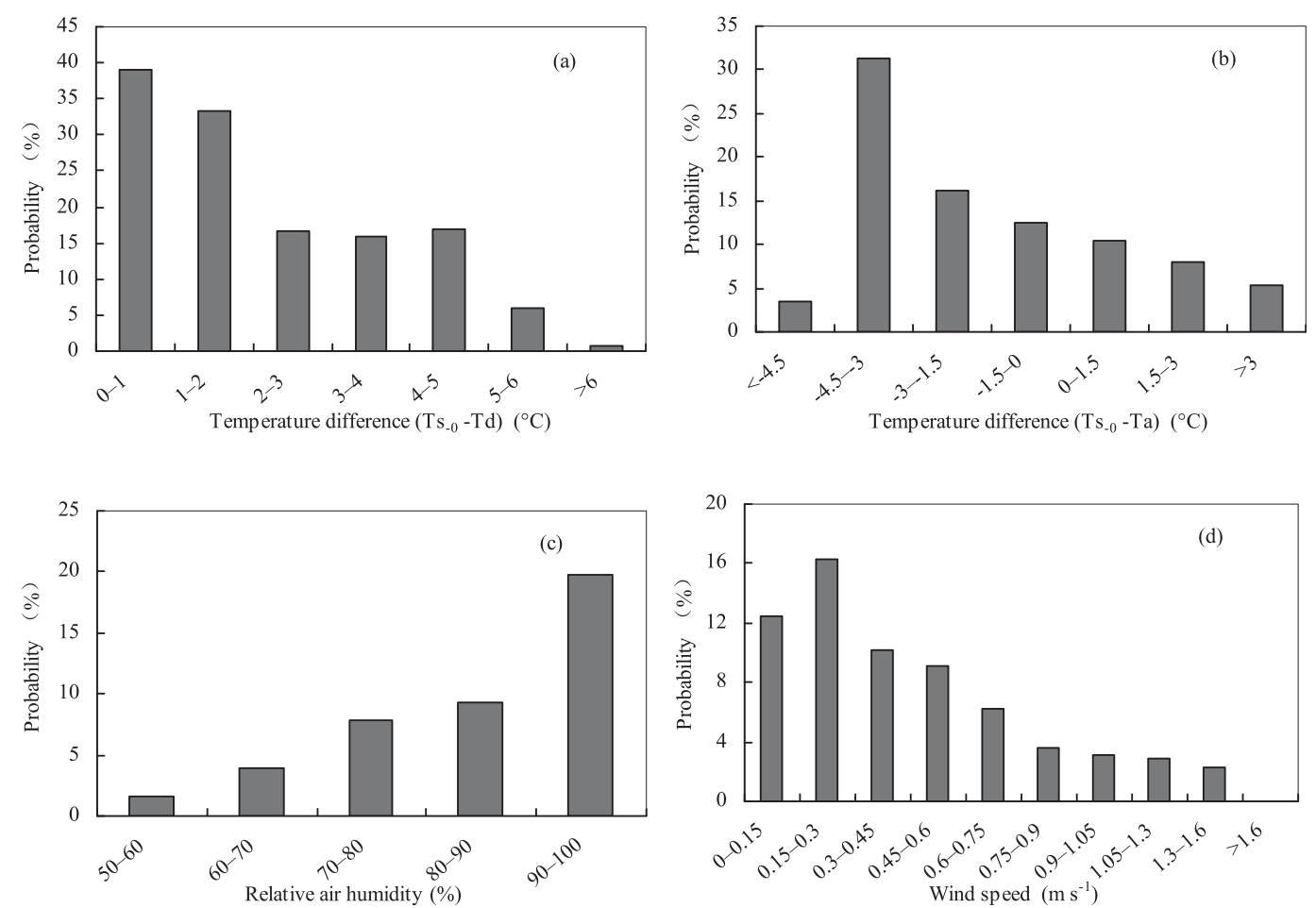

FIG. 12. Probability of soil surface condensation occurrence with meteorological conditions (a) differences between soil surface temperature and atmospheric dewpoint, (b) differences between soil surface and air temperature, (c) RH, and (d) wind speed.

addition, to match the in situ field environment and reduce boundary effects, the lysimeters were buried in the soil and surrounded with rice plants in all directions. All sensors used in the current research were calibrated to ensure their accuracy, and a special lysimeter with a fixed weight was used to eliminate sensor creep effects. Measurements of ET with the weighed microlysimeters closely matched measurements made with an eddy covariance system (Liu et al. 2018). Because of the boundary effect over smallsized lysimeters, the rice ET measured by microlysimeters was slightly higher than that obtained by eddy covariance, a method considered to underestimated rice ET due to an energy closure deficit. Therefore, the weighed microlysimeters were deemed to have accurately measured vapor condensation over the WSI rice fields, and only slightly overestimate ET because of the boundary effect. Accordingly, the contribution of vapor condensation to rice evapotranspiration in WSI paddy fields may have been underestimated in current research.

\section{b. Analysis of Cs occurrence links with environment conditions}

Generally occurring during sudden drops in $\mathrm{Ts}_{-0}-\mathrm{Td}$ within a range of $0^{\circ}-6^{\circ} \mathrm{C}, \mathrm{Cs}$ events were more common when $\mathrm{Ts}_{-0}>\mathrm{Td}$. Similar results were reported by
Heusinkveld et al. (2006), who observed that the dew formation process began when $\mathrm{Ts}_{-0}-\mathrm{Td}>10^{\circ} \mathrm{C}$. Several studies have shown vapor condensation or hygroscopic water to be formed when $\mathrm{Ts}_{-0}>\mathrm{Td}$ (Agam and Berliner 2004; Graf et al. 2004; Pan et al. 2010). This phenomenon can be partially ascribed to differences in temperature observation elevations. In the present study the $\mathrm{Td}$ was measured $2 \mathrm{~m}$ above the ground surface, such that Ta and $\mathrm{RH}$ at that height were lower than that at soil surface during the process of heat release from soil. This suggests that the temperature difference $\mathrm{Ts}_{-0}-\mathrm{Td}$ overestimated the real temperature difference between $\mathrm{Ts}_{-0}$ and Td near the soil surface. Meanwhile the high air RH $(>90 \%)$ and low $\theta$ in rice fields favored the occurrence of soil hygroscopic water, which also accounted for the occurrence of Cs events when $\mathrm{Ts}_{-0}>\mathrm{Td}$.

As the surface area of the rice crop canopy is large during most of the season, hourly Cs rates were much lower than Cc rates (Figs. 5-8). Diurnal variation analysis showed the onset of $\mathrm{Cc}$ to occur at sunset or slightly before sunset, whereas that of Cs occurred only after midnight in the early morning. This is likely attributable to the difference in canopy air and surface soil cooling processes. The canopy air temperature dropped sharply at sunset and quickly approached the dewpoint, whereas 
TABLE 2. The main water balance components in the WSI paddy field (mm).

\begin{tabular}{|c|c|c|c|c|c|c|}
\hline \multicolumn{4}{|c|}{ Input terms } & \multicolumn{3}{|c|}{ Output terms } \\
\hline \multirow[b]{2}{*}{ Precipitation $P$} & \multirow[b]{2}{*}{ Irrigation $I$} & \multicolumn{2}{|c|}{ Condensation water $(\mathrm{Cc}+\mathrm{Cs})$} & \multirow[b]{2}{*}{ Drainage $Q$} & \multicolumn{2}{|c|}{ Evapotranspiration (ET) } \\
\hline & & Canopy (Cc) & Soil (Cs) & & Evaporation $E$ & Transpiration $T$ \\
\hline 327.6 & 246.4 & 32.3 & 3.1 & 85.0 & 187.9 & 341.1 \\
\hline
\end{tabular}

changes in $\mathrm{Ts}_{-0}$ always lagged behind those of Ta, such that soil heat storage was released slowly over the several hours after sunset (Masseroni et al. 2015; Liu et al. 2018). This explains why, in rice fields, Cs events occurred much later than Cc events.

\section{c. Importance and contribution of vapor condensation to the rice field water budget}

While vapor condensation was well recognized as an important hydrometeorological process and water balance component in arid or semiarid areas, information on vapor condensation in humid areas was scarce. The seasonal vapor condensation rate in the WSI paddy field under a subtropical monsoon climate $(32.28 \mathrm{~mm}$ over rice canopy and $3.132 \mathrm{~mm}$ over soil) was higher than most results measured in upland fields. For example, annual vapor condensation in a dry desert valley of central Utah was measured at $29.31 \mathrm{~mm}$ (Malek et al. 1999) and at $33 \mathrm{~mm}$ in the western Negev Desert in Israel (Kidron et al. 2002). The quantity of seasonal vapor condensation measured in the present study was roughly twoto threefold greater that recorded for corn and soybean fields (Yan et al. 2010) and slightly greater than the amounts reported for a rice field in a humid temperate zone in northeastern China $(\mathrm{Cc}=26.2 \mathrm{~mm}$; Yan et al. 2010). This indicates that vapor condensation in rice fields in a subtropical monsoon climate is also an important water balance component and cannot be ignored.

The magnitude of water balance components in WSI paddy fields from tillering to yellow ripening are shown in Table 2. Seasonal rainfall and irrigation were 327.6 and $246.4 \mathrm{~mm}$, respectively. The seasonal condensation, $\mathrm{Cc}+\mathrm{Cs}$, was $35.4 \mathrm{~mm}$, under average hydrometeorology conditions and close to a routine irrigation quota. In this year, $\mathrm{Cc}+\mathrm{Cs}$ accounted for $10.8 \%$ of the rainfall and $14.4 \%$ of the seasonal irrigation, highlighting the fact that water vapor condensation represents an important source of water in WSI paddy fields in the humid climate.

Transpiration $T$ and ET over the season, including the revolatilization of vapor condensation over the soil surface or canopy surface, totaled 341.1 and $529.0 \mathrm{~mm}$, respectively (Table 2). When daily ET was determined by either the daily water balance calculation (Liu et al. 2018) or a daily energy balance calculation (Kalthoff et al. 2006), both Cc and Cs and their revolatilization were ignored in the calculation of $T$ and ET (termed as $T^{*}$ and $\left.\mathrm{ET}^{*}\right)$. For the WSI rice field under study, seasonal $T^{*}$ and $\mathrm{ET}^{*}$ were estimated at 308.8 and $493.6 \mathrm{~mm}$, and the contributions of $\mathrm{Cc} / T^{*}$ and $(\mathrm{Cc}+\mathrm{Cs}) / \mathrm{ET}^{*}$ were $10.4 \%$ and $7.2 \%$, respectively, thereby underestimating the rice crop's actual water requirements by $9.5 \%$ and underestimating the rice ET by $6.7 \%$. However, if the evapotranspiration is measured at an hourly scale using a micrometeorology method (e.g., eddy covariance), the measured daily ET is actually the paddy field's water consumption. That $6.7 \%$ of the daily crop ET came from revolatilization of the vapor condensation was previously unknown. Since vapor condensation was ignored in determining daily rice ET based on a daily water balance calculation, and in the irrigation scheduling to determine the appropriate irrigation volume, the irrigation demand was the same result whether or not a vapor condensation event was considered. Yet, this overlooked an important hydrometeorological component of the energy balance and underestimated the real crop water consumption capacity. Thus, quantifying vapor condensation is important in understanding the rice field's hydrometeorological and hydrological cycles, and it can be considered as a "free" form of irrigation, although it did not influence the result of irrigation scheduling based on daily water balance calculation.

\section{Conclusions}

Vapor condensation over plants $(\mathrm{Cc})$ and soil $(\mathrm{Cs})$ in WSI rice fields was measured separately using highprecision-weighed microlysimeters and mass balance calculation. This method is suitable for vapor condensation measurement in rice fields. Both the frequency of occurrence and magnitudes of $\mathrm{Cc}$ events were greater than those of $\mathrm{Cs}$ events. The $\mathrm{Cc}$ events occurred from sunset to sunrise, with a maximum rate of $0.096 \mathrm{~mm} \mathrm{~h}^{-1}$ occurring between 0400 and 0500 LT. Comparatively, Cs events occurred from 0100 to $1100 \mathrm{LT}$, with a maximum rate of $0.044 \mathrm{~mm} \mathrm{~h}^{-1}$ between 0700 and $0800 \mathrm{LT}$. The Cc events occurred not only when $\mathrm{Tc}<\mathrm{Td}$, but also occasionally during sudden drops in $\mathrm{Tc}-\mathrm{Td}$, even when Tc $>$ Td. Instances of Cs events generally occurred during a sudden drop in $\mathrm{Ts}_{-0}-\mathrm{Td}$, although in most cases $\mathrm{Ts}_{-0}>\mathrm{Td}$. The probability of occurrence of a 
Cc event was nearly $100 \%$ when $\mathrm{Tc}-\mathrm{Ta}<-4^{\circ} \mathrm{C}$ or $\mathrm{Tc}-\mathrm{Td}<0^{\circ} \mathrm{C}$. Overall, Cs events, including soil hygroscopic water, occurred in a larger proportion under conditions where $\mathrm{Ts}_{-0}-\mathrm{Td}>0$ or $\mathrm{Ts}_{-0}-\mathrm{Ta}>0$. Other than surface temperature, high ambient air humidity and low wind speed favored the occurrence of vapor condensation.

Over the growing season, Cc events occurred in 60 out of the 65 rain-free days $(92.3 \%)$, whereas Cs occurred in 33 of the 65 days $(50.8 \%)$. The rates of $\mathrm{Cc}$ and $\mathrm{Cs}$ and their frequency of occurrence were greater in the fall than in the summer. For the present study's WSI paddy field subject to a subtropical monsoon climate, the seasonal cumulative $\mathrm{Cc}$ and $\mathrm{Cs}$ were estimated as 32.3 and $3.1 \mathrm{~mm}$, respectively, higher than most results measured in upland fields. Their contribution to seasonal $T$ and $E$ were $9.5 \%$ and $1.6 \%$, respectively.

Accordingly, overlooking vapor condensation in WSI rice fields could underestimate the water consumption capacity in rice fields by $6.7 \%$. Vapor condensation in rice fields in a subtropical monsoon climate is an important component of the hydrological cycle and must accordingly be accounted for in the condensation and revolatilization process, as well as in the calculation of field water consumption and irrigation demand.

Acknowledgments. This work was supported by the National Key R\&D Program (2017YFC0403200), the Fundamental Research Funds for the Central Universities (2018B00414), the National Natural Science Foundation of China (51579070, 51479210), Jiangsu Province Water Conservancy Science and Technology Project (2015088), and the Priority Academic Program Development of Jiangsu Higher Education Institutions.

\section{REFERENCES}

Agam, N., and P. R. Berliner, 2004: Diurnal water content changes in the bare soil of a coastal desert. J. Hydrometeor., 5, 922-933, https://doi.org/10.1175/1525-7541(2004)005<0922: DWCCIT $>2.0 . \mathrm{CO} ; 2$.

— semi-arid environments-A review. J. Arid Environ., 65, 572-590, https://doi.org/10.1016/j.jaridenv.2005.09.004.

Allen, R. G., L. S. Pereira, D. Raes, and M. Smith, 1998: Crop evapotranspiration: Guidelines for computing crop water requirements. FAO Irrigation and Drainage Paper 56, 300 pp., www.fao.org/docrep/X0490E/X0490E00.htm.

Belder, P., B. Bouman, R. Cabangon, L. Guoan, E. Quilang, L. Yuanhua, J. Spiertz, and T. Tuong, 2004: Effect of watersaving irrigation on rice yield and water use in typical lowland conditions in Asia. Agric. Water Manage., 65, 193-210, https:// doi.org/10.1016/j.agwat.2003.09.002.

Ben-Asher, J., P. Alpert, and A. Ben-Zvi, 2010: Dew is a major factor affecting vegetation water use efficiency rather than a source of water in the eastern Mediterranean area.
Water Resour. Res., 46, W10532, https://doi.org/10.1029/ 2008WR007484.

Beysens, D., M. Muselli, V. Nikolayev, R. Narhe, and I. Milimouk, 2005: Measurement and modelling of dew in island, coastal and alpine areas. Atmos. Res., 73, 1-22, https://doi.org/10.1016/ j.atmosres.2004.05.003.

Clus, O., P. Ortega, M. Muselli, I. Milimouk, and D. Beysensal, 2008: Study of dew water collection in humid tropical islands. J. Hydrol., 361, 159-171, https://doi.org/10.1016/ j.jhydrol.2008.07.038.

Cui, Y., and J. Huang, 2012: A review of researches on efficient agricultural water use in China. Bull. Chin. Acad. Sci., 26 (1), $48-53$.

Ding, R., S. Kang, F. Li, Y. Zhang, L. Tong, and Q. Sun, 2010: Evaluating eddy covariance method by large-scale weighing lysimeter in a maize field of northwest China. Agric. Water Manage., 98, 87-95, https://doi.org/10.1016/j.agwat.2010.08.001.

Du, J., T. J. Jackson, R. Bindlish, M. H. Cosh, L. Li, and B. K. Hornbuckle, 2009: Passive microwave observations of soil moisture and dew in soil moisture experiments 2005 (SMEX05). Eos, Trans. Amer. Geophys. Union, 90 (Fall Meeting Suppl.), Abstract H11G-05.

Evett, S. R., R. C. Schwartz, T. A. Howell, R. Louis Baumhardt, and K. S. Copeland, 2012: Can weighing lysimeter ET represent surrounding field ET well enough to test flux station measurements of daily and sub-daily ET? Adv. Water Resour., 50, 79-90, https://doi.org/10.1016/j.advwatres.2012.07.023.

Glenn, D. M., C. Feldhake, F. Takeda, and D. L. Peterson, 1996: The dew component of strawberry evapotranspiration. HortScience, 31 (6), 947-950.

Goldsmith, G. R., N. J. Matzke, and T. E. Dawson, 2013: The incidence and implications of clouds for cloud forest plant water relations. Ecol. Lett., 16, 307-314, https://doi.org/10.1111/ele.12039.

Graf, A., W. Kuttler, and J. Werner, 2004: Dewfall measurements on Lanzarote, Canary Islands. Meteor. Z., 13, 405-412, https:// doi.org/10.1127/0941-2948/2004/0013-0405.

,-- , and -2008 : Mulching as a means of exploiting dew for arid agriculture? Atmos. Res., 87, 369-376, https://doi.org/ 10.1016/j.atmosres.2007.11.016.

Hanisch, S., C. Lohrey, and A. Buerkert, 2015: Dewfall and its ecological significance in semi-arid coastal south-western Madagascar. J. Arid Environ., 121, 24-31, https://doi.org/ 10.1016/j.jaridenv.2015.05.007.

Hao, X. M., C. Li, B. Guo, J. X. Ma, M. Ayupa, and Z. S. Chen, 2012: Dew formation and its long-term trend in a desert riparian forest ecosystem on the eastern edge of the Taklimakan Desert in China. J. Hydrol., 472-473, 90-98, https://doi.org/ 10.1016/j.jhydrol.2012.09.015.

Heusinkveld, B. G., S. M. Berkowicz, A. F. G. Jacobs, A. A. M. Holtslag, and W. C. A. M. Hillen, 2006: An automated microlysimeter to study dew formation and evaporation in arid and semiarid regions. J. Hydrometeor., 7, 825-832, https:// doi.org/10.1175/JHM523.1.

Hornbuckle, B. K., A. W. England, M. C. Anderson, and B. J. Viner, 2006: The effect of free water in a maize canopy on microwave emission at $1.4 \mathrm{GHz}$. Agric. For. Meteor., 138, 180-191, https://doi.org/10.1016/j.agrformet.2006.05.003.

Horton, R., and P. J. Wierenga, 1983: Estimating the soil heat flux from observations of soil temperature near the surface. Soil. Sci. Soc. Amer. J., 47, 14-20, https://doi.org/10.2136/ sssaj1983.03615995004700010003x.

, - — , and D. R. Nielsen, 1983: Evaluation of methods for determining the apparent thermal diffusivity of soil near the 
surface. Soil. Sci. Soc. Amer. J., 47, 25, https://doi.org/10.2136/ sssaj1983.03615995004700010005x.

Jackson, T. J., and L. Moy, 1999: Dew effects on passive microwave observations of land surfaces. Remote Sens. Environ., 70, 129-137, https://doi.org/10.1016/S0034-4257(99)00021-8.

Jacobs, A. F. G., 1994: Dew formation and the drying process within a maize canopy. Bound.-Layer Meteor., 69, 367-378, https://doi.org/10.1007/BF00718125.

— B. B. Heusinkveld, and S. M. Berkowicz, 2000: Dew measurements along a longitudinal sand dune transect, Negev Desert, Israel. Int. J. Biometeor., 43, 184-190, https://doi.org/ 10.1007/s004840050007.

,-- , and — 2002: A simple model for potential dewfall in an arid region. Atmos. Res., 64, 285-295, https://doi.org/ 10.1016/S0169-8095(02)00099-6.

,,-- R. J. Wichink Kruit, and S. M. Berkowicz, 2006: Contribution of dew to the water budget of a grassland area in the Netherlands. Water Resour. Res., 42, W03415, https://doi.org/ 10.1029/2005WR004055.

Kabela, E. D., B. K. Hornbuckle, M. H. Cosh, M. C. Anderson, and M. L. Gleason, 2009: Dew frequency, duration, amount and distribution in corn and soybean during SMEX05. Agric. For. Meteor., 149, 11-24, https://doi.org/10.1016/j.agrformet.2008.07.002.

Kalthoff, N., M. Fiebig-Wittmaack, C. Meißner, M. Kohler, M. Uriarte, I. Bischoff-Gauß, and E. Gonzales, 2006: The energy balance, evapo-transpiration and nocturnal dew deposition of an arid valley in the Andes. J. Arid Environ., 65, 420-443, https://doi.org/10.1016/j.jaridenv.2005.08.013.

Kato, Y., A. Henry, D. Fujita, K. Katsura, N. Kobayashi, and R. Serraj, 2011: Physiological characterization of introgression lines derived from an indica rice cultivar, IR64, adapted to drought and water-saving irrigation. Field Crops Res., 123, 130-138, https://doi.org/10.1016/j.fcr.2011.05.009.

Kidron, G. J., I. Herrnstadt, and E. Barzilay, 2002: The role of dew as a moisture source for sand microbiotic crusts in the Negev Desert, Israel. J. Arid Environ., 52, 517-533, https://doi.org/ 10.1006/jare.2002.1014.

Li, X. Y., 2002: Effects of gravel and sand mulches on dew deposition in the semiarid region of China. J. Hydrol., 260, 151-160, https://doi.org/10.1016/S0022-1694(01)00605-9.

Liu, W. J., J. M. Zeng, C. M. Wang, H. M. Li, and W. P. Duan, 2001: On the relationship between forests and occult precipitation (dew and fog precipitation). Ziran Ziyuan Xuebao, 16 (6), 517-575.

_ , Y. Zhang, Y. Liu, H. Li, and W. Duan, 2003: Comparison of fog interception at a tropical seasonal rain forest and a rubber plantation in Xishuangbanna, southwest China. Acta Ecol. Sin., 11 (11), 2379-2386.

Liu, X. Y., J. Z. Xu, S. H. Yang, and J. G. Zhang, 2018: Rice evapotranspiration on at the field and canopy scales under water-saving irrigation. Meteor. Atmos. Phys., 130, 227-240, https://doi.org/10.1007/s00703-017-0507-z.

Llorente, I., P. Vilardell, R. Bugiani, I. Gherardi, and E. Montesinos, 2000: Evaluation of BSPcast disease-warning system in reduced fungicide use programs for management of brown spot of pear. Plant Dis., 84, 631-637, https://doi.org/ 10.1094/PDIS.2000.84.6.631.

Lü, H. S., Z. B. Yu, Y. H. Zhu, S. Drake, and E. Sudicky, 2011: Dual state-parameter estimation of root zone soil moisture by optimal parameter estimation and extended Kalman filter data assimilation. Adv. Water Resour., 34, 395-406, https://doi.org/ 10.1016/j.advwatres.2010.12.005.

Luo, W., and J. Goudriaan, 2000: Measuring dew formation and its threshold value for net radiation loss on top leaves in a paddy rice crop by using the dewball: A new and simple instrument. Int. J. Biometeor., 44, 167-171, https://doi.org/10.1007/ s004840000071.

Madeira, A. C., T. J. Gillespie, and C. L. Duke, 2001: Effect of wetness on turfgrass canopy reflectance. Agric. For. Meteor., 107, 117-130, https://doi.org/10.1016/S0168-1923(00)00230-6.

Malek, E., G. D. McCurdy, and B. Giles, 1999: Dew contribution to the annual water balance in semi-arid desert valleys. J. Arid Environ., 42, 71-80, https://doi.org/10.1006/jare.1999.0506.

Masseroni, D., A. Facchi, M. Romani, E. A. Chiaradia, O. Gharsallah, and C. Gandolfi, 2015: Surface energy flux measurements in a flooded and an aerobic rice field using a single eddy-covariance system. Paddy Water Environ., 13, 405-424, https://doi.org/10.1007/s10333-014-0460-0.

Monteith, J. L., 1961: Dew: Facts and fallacies. The Water Relations of Plants, A. J. Rutter and F. H. Whitehead, Eds., Wiley, 37-55.

Moro, M. J., A. Were, L. Villagarcía, Y. Cantón, and F. Domingo, 2007: Dew measurement by eddy covariance and wetness sensor in a semiarid ecosystem of SE Spain. J. Hydrol., 335, 295-302, https://doi.org/10.1016/j.jhydrol.2006.11.019.

Pan, Y. X., X. P. Wang, and Y. F. Zhang, 2010: Dew formation characteristics in a revegetation-stabilized desert ecosystem in Shapotou area, northern China. J. Hydrol., 387, 265-272, https://doi.org/10.1016/j.jhydrol.2010.04.016.

Rothenberg, S. E., X. Feng, B. Dong, L. Shang, R. Yin, and X. Yuan, 2011: Characterization of mercury species in brown and white rice (Oryza sativa L.) grown in water-saving paddies. Environ. Pollut., 159, 1283-1289, https://doi.org/ 10.1016/j.envpol.2011.01.027.

Schmitz, H. F., and R. H. Grant, 2009: Precipitation and dew in a soybean canopy: Spatial variations in leaf wetness and implications for Phakopsora pachyrhizi infection. Agric. For. Meteor., 149, 1621-1627, https://doi.org/10.1016/j.agrformet.2009.05.001.

Singh, S. P., P. Khare, K. M. Kumari, and S. S. Srivastava, 2006: Chemical characterization of dew at a regional representative site of North-Central India. Atmos. Res., 80, 239-249, https:// doi.org/10.1016/j.atmosres.2005.09.003.

Uclés, O., L. Villagarcía, Y. Cantón, and F. Domingo, 2013: Microlysimeter station for long term non-rainfall water input and evaporation studies. Agric. For. Meteor., 182-183, 13-20, https://doi.org/10.1016/j.agrformet.2013.07.017.

$\longrightarrow,-$ M. J. Moro, Y. Canton, and F. Domingo, 2014: Role of dewfall in the water balance of a semiarid coastal steppe ecosystem. Hydrol. Processes, 28, 2271-2280, https://doi.org/ 10.1002/hyp.9780.

Verhoef, A., A. Diaz-Espejo, J. R. Knight, L. Villagarcia, and J. E. Fernandez, 2006: Adsorption of water vapor by bare soil in an olive grove in southern Spain. J. Hydrometeor., 7, 1011-1027, https://doi.org/10.1175/JHM556.1.

Wallin, J. R., 1967: Agrometeorological aspects of dew. Agric. Meteor., 4, 85-102, https://doi.org/10.1016/0002-1571(67)90014-3.

Wang, S., and Q. Zhang, 2011: Atmospheric physical characteristics of dew formation in semi-arid in Loess Plateau. Wuli Xuebao, 60, 059203, http://wulixb.iphy.ac.cn/CN/Y2011/V60/I5/059203.

Wen, X. F., X. Lee, X. M. Sun, J. L. Wang, Z. M. Hu, S. G. Li, and G. R. Yu, 2012: Dew water isotopic ratios and their relationships to ecosystem water pools and fluxes in a cropland and a grassland in China. Oecologia, 168, 549-561, https://doi.org/ 10.1007/s00442-011-2091-0.

Wilson, T. B., W. L. Bland, and J. M. Norman, 1999: Measurement and simulation of dew accumulation and drying in a potato canopy. Agric. For. Meteor., 93, 111-119, https://doi.org/ 10.1016/S0168-1923(98)00116-6. 
Xu, J. Z., S. Z. Peng, S. H. Yang, and W. G. Wang, 2012: Ammonia volatilization losses from a rice paddy with different irrigation and nitrogen managements. Agric. Water Manage., 104, 184-192, https://doi.org/10.1016/ j.agwat.2011.12.013.

Xu, Y. Y., B. X. Yan, and L. X. Wang, 2011: A research of dewfall in paddy. Zhongguo Nong Ye Ke Xue, 44 (3), 524-530.

Yan, B. X., and Y. Y. Xu, 2010: Method exploring on dew condensation monitoring in wetland ecosystem. Procedia Environ. Sci., 2, 123-133, https://doi.org/10.1016/j.proenv.2010.10.016. , — , and L. X. Wang, 2010: Dew condensation rules in farmland ecosystem in Sanjiang Plain. Acta Ecol. Sin., 30, $5577-5584$.
Ye, Y. H., K. Zhou, L. Y. Song, J. H. Jin, and S. L. Peng, 2007: Dew amounts and its correlations with meteorological factors in urban landscapes of Guangzhou, China. Atmos. Res., 86, 21-29, https://doi.org/10.1016/j.atmosres.2007.03.001.

Zhang, Q., S. Wang, F. L. Yang, P. Yue, T. Yao, and W. Y. Wang, 2015: Characteristics of dew formation and distribution, and its contribution to the surface water budget in a semi-arid region in China. Bound.-Layer Meteor., 154, 317-331, https://doi.org/10.1007/ s10546-014-9971-x.

Zhang, S. L., L. Lars, and G. Harald, 2007: Modeling the effects of mulching and fallow cropping on water balance in the Chinese Loess Plateau. Soil Tillage Res., 93, 283-298, https://doi.org/ 10.1016/j.still.2006.05.002. 